\title{
SELECTED ASPECTS OF MANAGEMENT METHODS USED BY COMPANIES IN PODLASKIE PROVINCE
}

\section{Wiesław MATWIEJCZUK ${ }^{1}$, Urszula KOBYLIŃSKA ${ }^{2}$}

\author{
${ }^{1}$ Prof. Eng., Head of the Chair of Organization and Management, Faculty of \\ Management, Bialystok University of Technology, Bialystok, Poland \\ e-mail: buj@interia.pl, phone: +48 85746 9853, \\ $2 \mathrm{PhD}$, Assistant Professor, Faculty of Management, Bialystok University of \\ Technology, Bialystok, Poland \\ e-mail: u.kobylinska@pb.edu.pl ,phone: +48 857469853
}

\begin{abstract}
Since the principles of the free market economy were introduced in Poland, the increased interest of managers has been noticed in acquiring modern management methods and implementing them in different spheres of business activity. More and more companies use benchmarking, outsourcing, lean management, strategic scorecard or competence management in their business practice. Awareness of managers regarding modern approaches that reflect the world's best practical achievements is important in itself. But no less important is the understanding that management methods cannot be always applied and not by everyone, so there are also some serious risks. Inappropriate use of the concept of management can lead a company to the crisis and fall when, in its turn, the proper understanding and its further application can protect the company against those risks. It is important to determine what for, when and how to use the concept.

This article presents the results of the pilot studies conducted among companies in Podlasie on the application and assessment of the suitability of modern management methods. The aim of the research presented in this article was to identify whether and to what extent the Podlasie companies use modern methods of management. The study was carried out in the first quarter of 2014 focusing on a sample of 104 randomly selected companies in Podlaskie province. The research method employed was a survey carried out among enterprises.
\end{abstract}

Keywords: modern management, methods of management, Podlaskie province JEL code: $D 200$

\section{Introduction}

Modern enterprise environment, characterized by, among others, deterioration of operating conditions, tightening competition, volatility of changes and presence of multiple constraints, determines the need to seek new ways of doing business and managing organizations. Management science presents various concepts and methods of management, to support enterprises in predicting, adapting and shaping the turbulent, changing environment. The changes are hardly predictable today as they are of the innovative nature, come quickly and cover the global space. 
In a so defined market environment, the need to improve competitiveness of the organization and achieve the greatest possible financial benefits becomes the most important objective of the company and it forces managers to reach for effective organizational solutions deriving from new management concepts. The tasks set for the modern management systems include adaptation of the company to turbulent market conditions, staying ahead of competitors, market monitoring and skillful use of signals on the opportunities and threats posed by the environment. Now managing a company requires development of effective approaches and methods for solving the tasks it faces. Therefore, knowledge about the possible use of new methods and systems in the company management, deriving from different organizational approaches, is important for today's managers. A method, in the context of management science, is a way of ensuring internal, temporal and logical adjustment of the management process. Management method will determine the manner of action and implementation of projects aimed at solving management problems emerging in the organization (Matwiejczuk, 2009). Describing, in more detail than in the method, how the activities are carried out within the framework of specific management techniques, which are characterized as routine methods, included in strict programs, such as algorithms or procedures (Kowalczewski, 2007). It can therefore be assumed that management techniques are particular patterns of conduct, the procedures by which management at different levels can coordinate staff activities so that under certain conditions, their goals are achieved. A system approach currently used in management forms management systems. They constitute one of the most popular tools for managing the organization. The management system is a set of solutions implemented in the organization to help in managing it effectively. The solutions apply to different aspects of business, including organizational structure, exploration of customer needs, communication within the organization, making purchases, etc. In practice, there are many business management systems that cover areas such as quality, environment, safety, financial management (Borys, Rogala, 2007).

This article presents the results of the pilot studies conducted among Podlasie managers on assessing the suitability and the scale of their exploitation of modern management methods. Empirical research was carried out in the first quarter of 2014 on a representative sample of companies from the region of Podlasie, it was a questionnaire survey. The results of preliminary studies will constitute the basis to conduct indepth theoretical analyzes and prepare a wide-ranging empirical research. 


\section{Purpose of research, research methodology and sample}

The aim of the research presented in this article was to identify whether and to what extent the Podlasie companies use modern methods of management. The results of the pilot studies carried out in the first quarter of 2014 focusing on a sample of 104 companies in the Podlasie province were chosen at random. The pilot studies were prepared on the basis of analysis of existing literature and research in this area. Research assumptions and some preliminary results were presented in the conference materials ( Kobylińska, Matwiejczuk, 2014).

The results of the pilot studies aimed to assess the scale and the scope of the use of modern management methods / systems are prepared in thematic blocks:

- the use of modern management methods/systems and their importance for the competitiveness of the company;

- the use of certified management systems and their importance for the competitiveness of the company;

- benefits of using modern management methods/systems;

- the degree of application and difficulties in the implementation of innovative solutions in the field of product or organization by the Podlasie companies;

- assessment of university-enterprise cooperation in the implementation of management methods or product and organizational improvements.

Prior to the formulated thematic block the research tasks were out forward.

The analyzed companies represented various entities from the point of view of the industry in which they operate, the number of employees, their operating range (table 1 ).

Table 1 Characteristics of the surveyed companies

(Source: own research)

\begin{tabular}{|l|l|l|l|l|l|}
\hline Sector & $\begin{array}{l}\text { The } \\
\text { number of } \\
\text { enterprises } \\
\text { (in \%) }\end{array}$ & $\begin{array}{l}\text { Number of } \\
\text { employees }\end{array}$ & $\begin{array}{l}\text { Response } \\
\text { rate }\end{array}$ & $\begin{array}{l}\text { Operating } \\
\text { range }\end{array}$ & $\begin{array}{l}\text { Response } \\
\text { rate }\end{array}$ \\
\hline Production & 43.3 & $1-10$ & 32.7 & Local & 21.2 \\
\hline Distribution & 1.9 & $11-50$ & 26.9 & Regional & 20.2 \\
\hline Trade & 25.0 & $51-250$ & 14.4 & National & 19.2 \\
\hline Services & 29.8 & above 251 & 26 & International & 39.4 \\
\hline
\end{tabular}




\section{Identification of management methods used by the Podlasie companies}

Analysis of the application of the management concept by the companies in Podlasie indicates that the vast majority of them use several methods simultaneously. The most popular is CRM $(54.8 \%$ of the respondents), Controlling $(52.9 \%$ of the respondents), logistics management (53.8\% of the respondents) and competence management (43.3\% of the respondents). Less popular methods include strategic management $(42.3 \%$ of the respondents), knowledge management (41.3\% of the respondents) or outsourcing (35.6\%). The least of Podlasie companies use the 6sigma method, reengineering and strategic scorecard. Their share in the practice of companies is marginal. A detailed scheme of responses is reflected in figure 1.

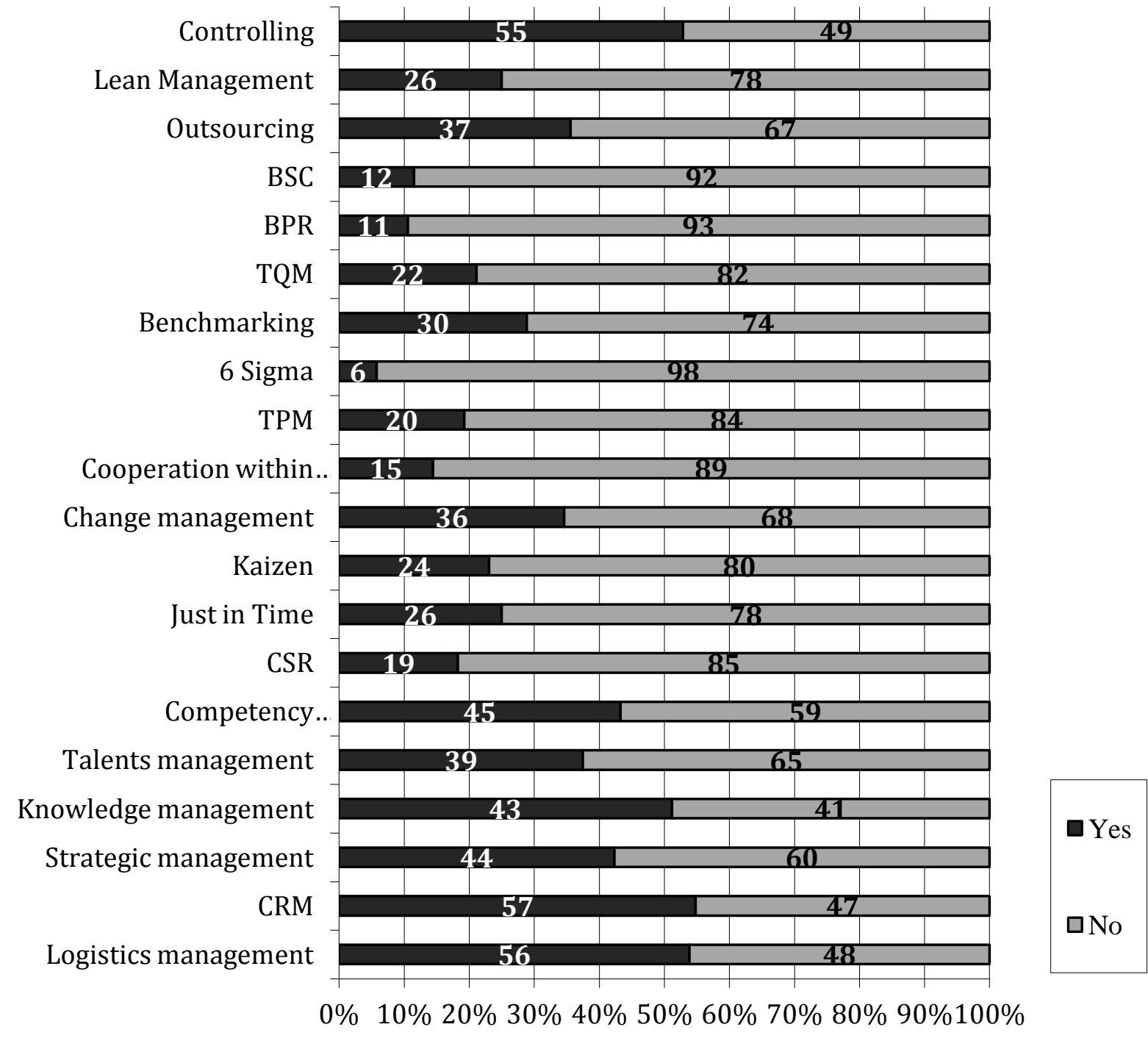

Fig. 1 Management methods used by the Podlasie companies (Source: own research) 
Popularity of controlling and outsourcing is not surprising, as since the 90s of the last century they have been among the most widely used methods of business management, mainly in the manufacturing industry. This is largely due to the historical circumstances in which the individual companies functioned and also restructuring activities undertaken by them since the mid 90's of the last century (Lisiński, Sroka, Brzezinski, 2012).

On the other hand, a small proportion of the methods such as 6Sigma, Business Process Reengineering or the Balanced Scorecard (BSC) may be due to poor knowledge of these somehow strange-sounding methods and significant costs associated with their implementation. Furthermore, the effectiveness of these methods and their usefulness is described in the literature mainly for large enterprises, which are not numerous in Podlasie province.

Analysis of the implemented methods in the industry in which the company operates can be concluded with a statement that manufacturing companies more often use management methods than those in the trade and service sectors. This is partly due to the specifics of the processes implemented in production and the fact that some management methods are strictly related to production, such as for example: Total Productive Maintenance (TPM), Just in Time (JIT) logistics management. Detailed results of the research in this area are presented in table 2.

Table 2 The methods used and the business sector $(\mathrm{N}=104)$

(Source: own research)

\begin{tabular}{|c|c|c|c|c|}
\hline \multirow{2}{*}{ Method } & $\begin{array}{l}\text { Production } \\
(\mathrm{N}=45)\end{array}$ & $\begin{array}{l}\text { Distribution } \\
(\mathrm{N}=2)\end{array}$ & Trade $(\mathrm{N}=26)$ & \begin{tabular}{|l} 
Services \\
$(\mathrm{N}=\mathbf{3 1})$
\end{tabular} \\
\hline & $\begin{array}{l}\text { The number } \\
\text { of enterprises }\end{array}$ & $\begin{array}{l}\text { The number } \\
\text { of enterprises }\end{array}$ & $\begin{array}{l}\text { The number } \\
\text { of enterprises }\end{array}$ & $\begin{array}{l}\text { The number } \\
\text { of enterprises }\end{array}$ \\
\hline Controlling & 26 & 1 & 16 & 12 \\
\hline \begin{tabular}{|l|} 
Logistic \\
Management
\end{tabular} & 26 & 2 & 15 & 13 \\
\hline CRM & 24 & 2 & 15 & 16 \\
\hline \begin{tabular}{|l|} 
Strategic \\
Management
\end{tabular} & 22 & 2 & 10 & 10 \\
\hline \begin{tabular}{|l|} 
Change \\
Management
\end{tabular} & 20 & 1 & 6 & 9 \\
\hline \begin{tabular}{|l} 
Knowledge \\
Management
\end{tabular} & 20 & 0 & 10 & 13 \\
\hline JIT & 19 & 0 & 2 & 5 \\
\hline Outsourcing & 19 & 0 & 11 & 7 \\
\hline \begin{tabular}{|l|} 
Competence \\
Management
\end{tabular} & 19 & 1 & 14 & 11 \\
\hline
\end{tabular}




\begin{tabular}{|l|l|l|l|l|}
\hline $\begin{array}{l}\text { Talent } \\
\text { Management }\end{array}$ & 18 & 0 & 11 & 10 \\
\hline Kaizen & 17 & 0 & 3 & 4 \\
\hline $\begin{array}{l}\text { Lean } \\
\text { Management }\end{array}$ & 17 & 0 & 5 & 4 \\
\hline TPM & 17 & 0 & 0 & 3 \\
\hline Benchmarking & 16 & 0 & 8 & 6 \\
\hline TQM & 12 & 0 & 6 & 4 \\
\hline CSR & 11 & 0 & 4 & 4 \\
\hline $\begin{array}{l}\text { Cooperation } \\
\text { within the } \\
\text { cluster }\end{array}$ & 9 & 0 & 3 & 3 \\
\hline BPR & 5 & 0 & 4 & 2 \\
\hline 6 Sigma & 4 & 0 & 0 & 2 \\
\hline BSC & 3 & 1 & 3 & 2 \\
\hline
\end{tabular}

In another question, the respondents pointed to the certified management systems they have. In this respect, the most popular was a certified quality management system (ISO 9001) - owned by $31.7 \%$ of the respondents. Subsequently, the respondents indicated work safety and hygiene management system $\mathrm{PN}-\mathrm{N}-18001$ (26.9\% response rate). Less than one in five respondents had environmental system - ISO 14001, and the least popular was certified information management system - ISO 27001.

Table 3 Certificates by the Podlasie company (Source: own research)

\begin{tabular}{|l|l|l|l|l|l|l|}
\hline \multirow{2}{*}{$\begin{array}{l}\text { Certified } \\
\text { management } \\
\text { system }\end{array}$} & Yes & No & \multicolumn{2}{l|}{ Together } \\
\cline { 2 - 7 } & Number & $\%$ & Number & $\%$ & Number & \% \\
\hline ISO 9001 & 33 & 31.7 & 71 & 68.3 & 104 & 100.0 \\
\hline ISO 14001 & 18 & 17.3 & 86 & 82.7 & 104 & 100.0 \\
\hline PN-N 18001 & 28 & 26.9 & 76 & 73.1 & 104 & 100.0 \\
\hline IS0 27001 & 8 & 7.7 & 96 & 92.3 & 104 & 100.0 \\
\hline
\end{tabular}

One can easily notice, while analyzing certifications of management systems by industry, that mainly manufacturing companies had them (they got a total of 58 certificates). The most popular certification in the industry was ISO 9001. This is not a surprise, as companies strive for ISO 9001 certification often for marketing reasons. The quality system may be a message to the client that the company is working to improve product performance and it is customer-oriented. Subsequent firms which implemented certified management systems were service companies (16 certificates). Surprisingly most popular in the industry 
was a certified system of health and safety. Undoubtedly, safety certification influences improvement of working conditions in the company and can increase employees' satisfaction with the job, even if it is the service industry where you do not identify as many hazards and occupational risks as there are on production. Trading companies had a total of 9 certificates. Their share in the total number of companies in this sector was the smallest (table 4).

Table 4 Certificates by Podlasie companies by industry

(Source: own research)

\begin{tabular}{|l|l|l|l|l|l|l|l|l|}
\hline \multirow{2}{*}{ Certificate } & Production & \multicolumn{2}{l|}{ Distribution } & Trade & \multicolumn{2}{l|}{ Services } \\
\cline { 2 - 9 } & Number & $\mathbf{0}$ & Number & $\mathbf{\%}$ & Number & $\%$ & Number & $\%$ \\
\hline ISO 9001 & 25 & 55.6 & 1 & 50.0 & 3 & 8.3 & 4 & 12.9 \\
\hline ISO 14001 & 15 & 33.3 & 0 & 0.0 & 1 & 3.8 & 2 & 6.5 \\
\hline PN-N 18001 & 15 & 33.3 & 2 & 100.0 & 3 & 8.3 & 8 & 25.8 \\
\hline ISO 27001 & 3 & 6.7 & 1 & 50.0 & 2 & 7.7 & 2 & 6.5 \\
\hline
\end{tabular}

The last question in this part of the survey was concerned with cooperation of universities and the researched companies in introducing product and organizational innovations, and contemporary management methods. Only less than $8 \%$ of the respondents declared cooperation with a university in this aspect. The remaining $92 \%$ had no experience in cooperation with universities at all (Figure 2).

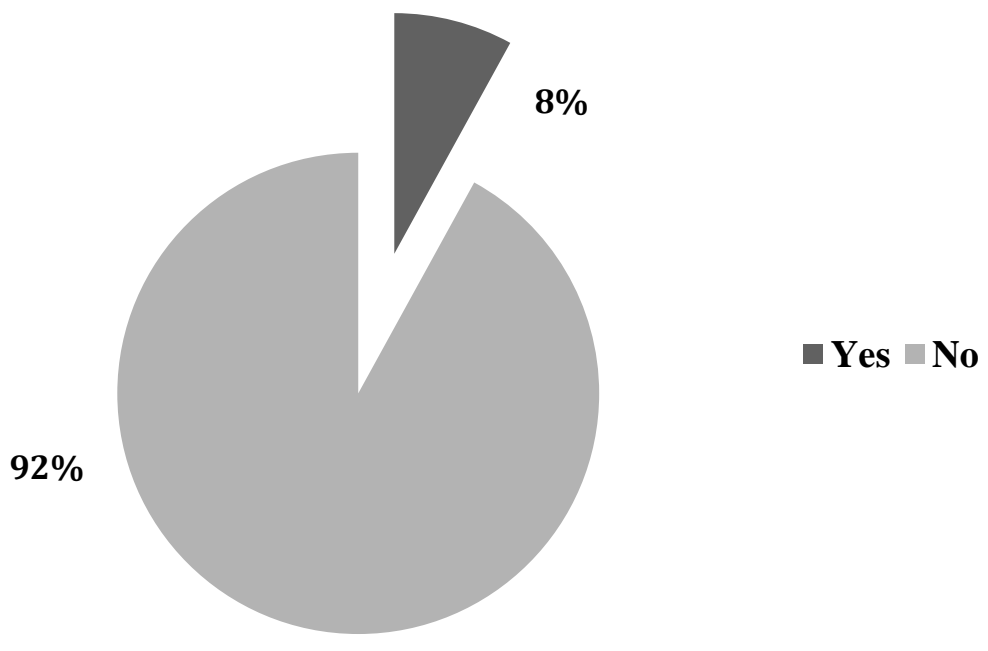

Fig. 2 Has the company ever cooperated with a university in the implementation of product and organizational innovations or management methods?

(Source: own research) 
Causes of poor cooperation between companies and universities seem puzzling (table 5).

Table 5 Reasons for failing to cooperate with the university (Source: own research)

\begin{tabular}{|l|l|l|}
\hline Lp & Cause & \% of responses \\
\hline 1. & There is no need & 46.15 \\
\hline 2. & $\begin{array}{l}\text { We have no access to the information about the } \\
\text { university offer }\end{array}$ & 33.6 \\
\hline 3. & It does not pay us & 6.7 \\
\hline 4. & Other & 4.8 \\
\hline
\end{tabular}

The most frequently mentioned reasons for failing to cooperate with universities are no need for co-operation (46.15\% response rate), and lack of access to the information about the services offered by universities (33.6\% response rate).

\section{Benefits and barriers to the use of management methods in enterprises}

In the next question, the respondents had to indicate the benefits of the use of modern management methods, assigning them rank in the scale of 1-5. The following table 6 summarizes the results of these research.

Table 6 Benefits of using modern management (Source: own research)

\begin{tabular}{|l|l|l|}
\hline Lp & Benefits & Importance (1-5)* $^{*}$ \\
\hline 1 & Better meet customer needs & 4.28 \\
\hline 2 & Increased effectiveness & 4.05 \\
\hline 3 & Improving the company's competitive position & 4.00 \\
\hline 4 & Improving the image of the company & 3.97 \\
\hline 5 & Minimizing operations costs & 3.92 \\
\hline 6 & Increasing the value of the company & 3.83 \\
\hline 7 & Widening the scope of the company & 3.63 \\
\hline 8 & Increase in employee satisfaction & 3.45 \\
\hline 9 & Strengthening relationships with suppliers & 3.42 \\
\hline
\end{tabular}

*1 - least important; 5 - most important

Analysis of the benefits of using modern management methods leads to the conclusion that the surveyed companies indicated almost the same importance of various benefits in improving their competitiveness. The decisive advantage of this evaluation is to better meet customer needs (average score - 4.28). Further high scores received the following 
benefits: increased performance efficiency (average - 4.05), the improvement of the competitive position (average - 4.0). The studied companies see the smallest benefits in the following areas: increasing employees' satisfaction (average score 3.45) and strengthening relationships with suppliers (average score - 3.42).

Apart from the above mentioned research results, clear benefit from the application of modern management methods is a better preparation of companies to face competition by meeting the demands of modern trends in competitiveness. As a result, the firm will have better prospects for survival and growth in a highly turbulent environment.

The Podlasie entrepreneurs were also asked a question about the barriers that limit the ability to implement modern management methods. Most respondents indicated such restrictions as high costs of implementation, lack of time or insufficient knowledge of the implemented management methods, along with no external support (table 7). Quite significant are also barriers involving the lack of faith and positive examples in the application of these methods, and employee resistance to all types of change.

Table 7 Barriers to implementation of modern management methods (Source: own research)

\begin{tabular}{|l|l|l|}
\hline $\mathbf{L p}$ & Barrier & $\begin{array}{l}\text { Importance } \\
(\mathbf{1 - 5})^{*}\end{array}$ \\
\hline 1. & High costs of implementation & 3.7 \\
\hline 2. & No time for implementation & 3.1 \\
\hline 3. & Lack of knowledge of / methods / management system & 2.8 \\
\hline 4. & $\begin{array}{l}\text { No external support (EU funds, cooperation with a } \\
\text { university, local government) }\end{array}$ & 2.8 \\
\hline 5. & Claim of uselessness & 2.6 \\
\hline 6. & Employee resistance & 2.4 \\
\hline 7. & Ignorance of the existence of methods & 2.4 \\
\hline 8. & Fear of change & 2.3 \\
\hline
\end{tabular}

*1 - least important; 5 - most important

\section{Conclusions and suggestions}

The analysis made in this article confirms that many of the surveyed companies located in Podlaskie province take actions fully referring to the contemporary management trends in the global science and practice. This analysis was made on the basis of surveys conducted.

The results of the studies conducted and presented in this article indicate that the companies in Podlasie know and use modern methods of management, although the degree of their use and usefulness varies. The 
scope of application of modern management methods in enterprises in Podlasie, primarily depends on such factors as the nature of a company, its size and operation range.

The level of knowledge and personal commitment of management staff, the financial situation and the current competitive position of a company are also important. Making managers aware that strategic partnerships for cooperation are key success factors in business facing global competition (YL Doz, G. Hamel, 2006) will force them to look for new sources of competitive advantage. What connects all modern concepts - starting from ME Porter, through G. Hamel and CK Prahalad, and ending on works of W.Ch. Kim and R. Mauborqne (ME Porter, 1985; Fang Lee Cooke, 2008; Hamel G., Prahalad CK, 1994; Hunt SD, Morgan RM, 1996; Ray G., J. Barney, Muhanna W., 2004; Kim W.Ch., Mauborqne R., 2005 ) - is that outstanding results require exceptional and non-standard measures. Each organization ought to take action that will build its uniqueness in the market, giving a competitive advantage and ensuring higher-than-average results at the same time.

The message of this article is addressed not only to the companies in Podlasie. Active scrutiny of the market, also in terms of modern management, is advisable and the methods that can be helpful in improving competitive potential and building competitive advantages should be used. Taking into consideration the predominance of opportunities and benefits over costs and risks we should note that the concepts used reasonably make nowadays an objective necessity not just a trend. Therefore, while maintaining situational conditions and mutual complementarities, they should be implemented and used in practice.

The presented results of the pilot studies imply the need for further research on the analyzed issues.

\section{References}

1. BORYS T., ROGALA P., (2007). Systemy zarządzania jakościa i środowiskiem, Wyd. AE we Wrocławiu, Wrocław, pp. 88-91.

2. DOZ Y.L., HAMEL G., (2006). Alianse strategiczne, Sztuka zdobywania korzyści poprzez współpracę, Wyd. Helion, Gliwice.

3. FANG LEE COOKE, (2008). Competition and strategy of Chinese firms, „Competitiveness Review”, 18(1-2).

4. HAEL G., PRAHALAD C.K., (1994) Competing for the Future, Harvard Business School Press, Boston.

5. HUNT S.D., MORGAN R.M, (1996). The resource advantage theory of competition. Dynamics, path dependencies, and evolutionary dimensions, "Journal of Marketing", 60.

6. KIM W.Ch., MAUBORQNE R., (2005) Blue Ocean Strategy. How to Create Uncontested market Space and Make Competition Irrelevant, Harvard Business School Publishing Corporation, Boston. 
7. KOBYLIŃSKA U., MATWIEJCZUK W., (2014). The use of concepts and metohods of management by companies in Podlaskie province, International Scientific Conference: catching up new ideas: Management, economics and law'2014: collection of scientific articles, CD materials, Kauno Kolegija, University of Applied Sciences, Kaunas, pp. 88-91.

8. KOWALCZEWSKI W. (2007). Instrumenty stosowane $w$ zarzqqdzaniu, „Kierunki i metody zarządzania przedsiębiorstwem", ed. by W. Kowalczewskiego i W. Matwiejczuka, Difin, Warszawa, p. 21.

9. LISIŃSKI M., SROKA W., BRZEZIŃSKI P., (2012). Nowoczesne koncepcje zarządzania kierowaniu przedsiębiorstwami - wyniki badań, „Przegląd organizacji", No 1, p. 27.

10. MATWIEJCZUK W. (red.), (2009). Koncepcje i metody zarządzania, Wyd. PB, Białystok, p. 9.

11. PORTER M.E., (1985). Competitive Advantage, Free Press, New York.

12. RAY G., BARNEY J., MUHANNA W., (2004). Capabilities, business processes, and competitive advantage: choosing the dependent variable in empirical tests of the resource-based view, „Strategic Management Journal”, 25(1).

\title{
ATSEVIŠĶI PĀRVALDĪBAS METOŽU ASPEKTI, KO IZMANTO UZNEĒMUMI PODLASES VOJEVODISTE
}

\author{
Wiesław MATWIEJCZUK ${ }^{1}$, UrSzula KOBYLIŃSKA ${ }^{2}$ \\ ${ }^{1}$ Prof. Eng., Belastokas Tehnologiju universitātes, Pārvaldības fakultātes, \\ Organizācijas un pārvaldības katedras vadītājs, Belastoka, Polija, \\ 2 PhD, Belastokas Tehnoloǵiju universitātes, Pārvaldības fakultātes docente, \\ Belastoka, Polija
}

Kopsavilkums

Mūsdienu vadības zinātne piedāvā dažādas vadības metodes un koncepcijas, lai atbalstītu uzn̄ēmumus, prognozējot, pielāgojot un veidojot nepastāvīgu, mainīgu vidi. Mūsdienās šīs izmain,as ir grūti prognozējamas, jo tās ir novatoriskas, pēkšñas un aptver visu pasauli. Šādi definētā tirgus vidē nepieciešamība uzlabot organizācijas konkurētspēju un sasniegt iespējami lielāku finansiālu labumu kḷūst par svarīgāko uzṇēmuma mērḳi un liek vadītājiem sniegties pēc efektīvākiem organizatoriskiem risinājumiem, kas izriet no jaunām pārvaldības koncepcijām. Uzdevumi, kas izvirzīti mūsdienu pārvaldības sistēmām, ietver uzṇēmuma pielāgošanos svārstīgiem tirgus apstākḷiem, konkurentu apsteigšanu, tirgus uzraudzību un signālu par iespējām un draudiem, ko rada vide, prasmīgu izmantošanu. Mūsdienās uzñēmuma pārvaldībai ir būtiska efektīvu darbību un metožu izstrāde, lai atrisinātu uzdevumus, ar kuriem tā saskaras, tādēl, mūsdienu vadītājiem ir nepieciešamas zināšanas par jauno metožu, kas izriet no dažādām organizatoriskām pieejām, iespējamo izmantošanu uzṇēmuma pārvaldībā.

Raksts iepazīstina ar eksperimentālo pētījumu Podlases vadītāju vidū, kas tika veikts, lai noteiktu moderno pārvaldības metožu izmantošanas piemērotību un apjomu. Empīrisks pētījums, kas ietvēra anketēšanu, tika veikts 2014. gada pirmajā ceturksnī, izmantojot reprezentatīvu izlasi, ko veidoja uzṇēmumi no Podlases vojevodistes. Pētījumu rezultātu analīze pierādīja, ka daudzi no aptaujātajiem 
uzṇēmumiem, kas atrodas Podlases vojevodistē, veic darbību saskaṇā ar mūsdienu pārvaldības tendencēm, kas sastopamas pasaules zinātnē un praksē. Veiktā pētījuma rezultāti, kuri ir atspoguḷoti šajā rakstā, liecina, ka uzṇēmumi Podlases vojevodistē zina un izmanto mūsdienīgas pārvaldības metodes, lai gan to izmantošanas un lietderības pakāpe atšksiras. Moderno pārvaldības metožu piemērošanas apjoms uzṇēmumos Podlases vojevodistē galvenokārt ir atkarīgs no tādiem faktoriem kā uzñēmuma veids, lielums un darbības sfēra.

Atslēgas vārdi: mūsdienīgā pārvaldība, pārvaldības metodes, Podlases vojevodiste. 